\title{
Ischemic Stroke In infant With Tetralogy of Fallot
}

\author{
Hamama Pitra, DA ${ }^{1}$, Susanti L ${ }^{2}$ \\ ${ }^{11}$ Bagian Neurologi Fakultas Kedokteran Universitas Baiturrahmah, Padang, Indonesia \\ E-mail : dianayuhamamapitra@fk.unbrah.ac.id \\ ${ }^{2}$ Bagian Bagian Neurologi Fakultas Kedokteran Universitas Andalas, Padang, Indonesia
}

\begin{abstract}
Objectives: Although stroke is often viewed as occurring primarily in the elderly, it also strikes infants, children, young adults. Stroke in children are rare but increasingly important conditions due to the severity of their complications and diverse diagnostic differentials. It is not yet clearly understood and with multifactorial etiologies. When it comes to stroke, children are not just little adults. Stroke risk factors, symptoms, prevention efforts, and treatment are often different in children than in adults. Up to $80 \%$ of children with ischemic stroke have cardiovascular disease. Case report: RS, An infant, aged two and half years old was admitted to DR. M. Djamil hospital Padang, with right hemiplegy and developed aphasia after activity. One year ago, he had history of cyanotic skin but neglected by his parents and never sought medical treatment. Physical findings on this patient are cyanosis and clubbing fingers. Cardiac auscultation revealed a pansystolic murmur grade III-IV best heard at the upper left sternal border. Chest radiograph showed a characteristic "bootshaped" heart, which is a reflection of Right Ventricular (RV) hypertrophy. The ECG showed right axis deviation. Brain CT Scan revealed a large hypodense lesion on the left cerebral hemisphere suggested as large brain infarction. Echocardiogram revealed tetralogy of fallot with a larged malaligned ventricular septal defect (VSD) with $60 \%$ aortic override. Patient was managed conservatively. After two weeks of admission, patient was discharged with improvement.Conclusion : Ischemic stroke in this infant with tetralogy of fallot occurred via paradoxical embolism mechanism.
\end{abstract}

Katakunci — Ischemic stroke, Tetralogy of Fallot, Large brain infarct, Paradoxical Embolism.

\begin{abstract}
Background: Meskipun stroke sering terjadi pada usia tua namun juga dapat terjadi pada balita, anak-anak, dan dewasa muda. Stroke pada anak merupakan kejadian yang jarang namun merupakan kondisi yang perlu mendapatkan perhatian khusus karena beratnya komplikasi yang ditimbulkan dan diagnosis banding yang banyak. Stroke pada anak masih belum dipahami dan dengan etiologi multipel. Penanganan kasus stroke pada anak tidak sederhana karena anak bukanlah dewasa kecil. Faktor risiko, gejala, terapi serta pencegahan berbeda pada anak. Lebih $80 \%$ anak dengan stroke memiliki kelainan jantung. Laporan kasus ini bertujuan untuk membahas diagnosis dan penatalaksanaan balita dengan stroke iskemik.

Laporan Kasus: Seorang balita, RS, berumur 2,5 tahun datang dengan keluhan lumpuh tubuh sebelah kanan dan afasia. Satu tahun yang lalu, pasien memiliki riwayat kulit kebiruan namun tidak pernah berobat. Pemeriksaan fisik ditemukan sianosis terutama pada distal dan clubbing fingers. Pemeriksaan auskultasi jantung ditemukan bising pansistolik grade III-IV yang paling jelas terdengar di bagian atas linea sternalis sinistra. Pemeriksaan rontgen thorak menunjukkan karakteristik "bootshaped" yang menunjukkan hipertrofi ventrikel kanan. Rekaman EKG menunjukkan right axis deviation (RAD). Brain CT Scan terdapat lesi hipodens luas di hemisfer serebri kiri. Pemeriksaan ekokardiografi menunjukkan tetralogy fallot with larged malaligned ventricular septal defect (VSD) with $60 \%$ aortic override. Pasien ditatalaksana secara konservatif. Pasien dipulangkan dengan perbaikan klinis. Kesimpulan : Stroke iskemik pada balita dengan tetralogy fallot terjadi melalui mekanisme emboli paradox
\end{abstract}

Keywords - Stroke iskemik, Tetralogy of fallot, Infark luas, emboli paradoks

Health \& Medical Journal 


\section{INTRODUCTION}

Although stroke is often viewed as occurring primarily in the elderly, it also strikes infants, children, and young adults. ${ }^{1,2,3,4,5}$ Stroke in children are rare but increasingly important conditions due to the severity of their complications and diverse diagnostic differentials. ${ }^{1,3,6,7,8}$ It is not yet clearly understood and with multifactorial etiologies. $^{4}$ When it comes to stroke, children are not just little adults. Stroke risk factors, symptoms, prevention efforts, and treatment are often different in children than in adults. ${ }^{1,6}$ Stroke type also varies according to age. In adults, $80 \%$ to $85 \%$ of strokes are ischemic and the rest are hemorrhagic. In children, $55 \%$ of strokes are ischemic and the remainder are hemorrhagic. ${ }^{1}$ Up to $80 \%$ of children with ischemic stroke have cerebrovascular disease. ${ }^{1,5,6}$

Tetralogy of Fallot is the most common congenital heart disease with incidence 9-14 $\%$. TF remains the most common type of congenital heart lesion seen beyond infancy and childhood with about $5 \%$ of patients surviving to the age of 40 years. ${ }^{9}$ We report an interesting association between tetralogy of Fallot and ischemic stroke in infant. Although it is often causing brain abscess, tetralogy of Fallot is considered as one of etiological factor of stroke in children, albeit unclear mechanism of disease.

\section{Case Report}

RS, An infant, aged two and half years old was admitted to DR. M. Djamil hospital Padang, with right hemiplegy after activity and aphasia. Previously he complained breathlessnes after physical activity, bluished around lips and finger toes, and he suddenly fell down. He was not able to move his right limbs, accompanied by right facial weakness and unable to speech (only crying). One year ago, he had history of cyanosis but neglected by his parents and never sought medical treatment. There was no family history of cardiac diseases nor vascular diseases.

$\mathrm{He}$ was alert with no breathlessness and no fever. His blood pressure was 100/60 mmHg. The pulse was regular with a rate of 96 beats per minute. Cardiac auscultation revealed a pansystolic murmur grade III-IV best heard at the upper right sternal border. The neurological examination revealed right facial nerve palsy (UMN sign), and right hemiplegia with hypertonus and hyperreflexia. He was aphasic, with global comprehension language disorders. Chest radiograph showed a characteristic "bootshaped" heart, which is a reflection of Right Ventricular (RV) hypertrophy. The ECG showed sinus rhythm, prolonged PR interval, and right axis deviation. Brain CT Scan revealed a large hypodens lesion on the left cerebral hemisphere suggested as large brain infarction.

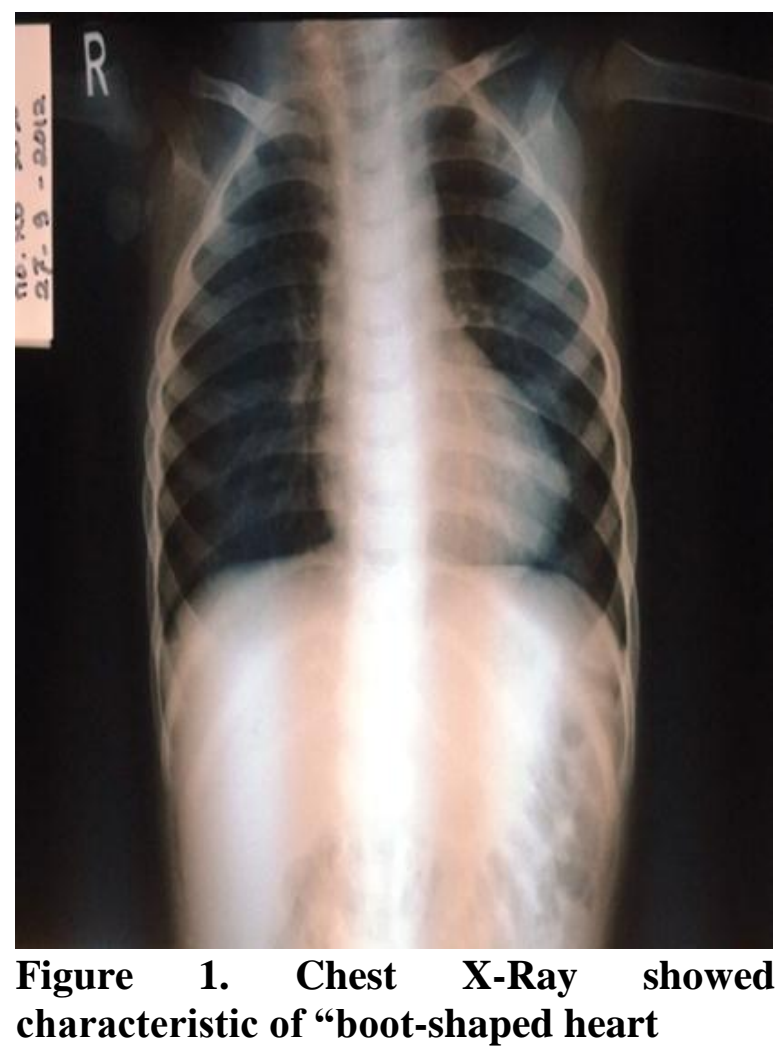




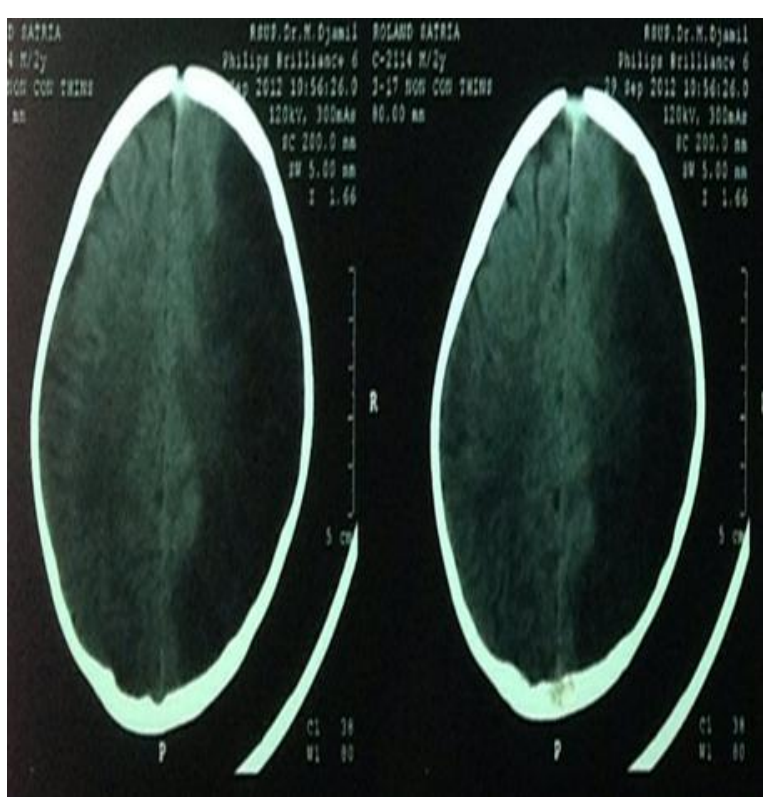

Figure 2. Brain CT Scan revealed a large hypodens lesion on the left cerebral hemisphere suggested as large brain infarction

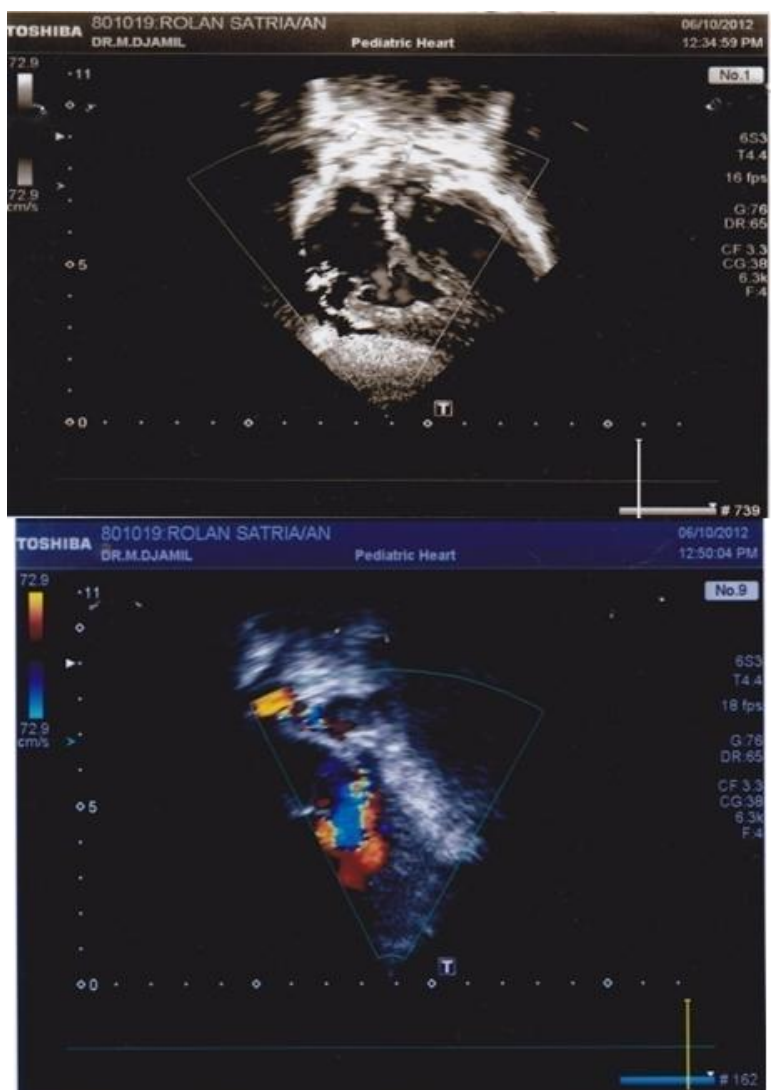

Figure 3. Echocardiogram revealed Tetralogy of Fallot with a larged malaligned ventricular septal defect (VSD) with $>50 \%$ aortic override
An echocardiogram revealed tetralogy of fallot with a larged malaligned ventricular septal defect (VSD) with $>50 \%$ aortic override. The aortic valve was trileaflet. There was no sign of atrial septal defect (ASD). Sign of pulmonary atresia was noted as there was no flow to pulmonary artery. The ejection fraction was $80 \%$. Final conclusion of echocardiogram was Tetralogy of fallot.

A final diagnosis of cardioembolic stroke associated with tetralogy of Fallot was considered. The patient was managed conservatively although there are no specific guidelines currently in place for the treatment of stroke in children in which central elements include support treatment, monitoring, and anticoagulation as secondary prevention in certain cases. The patient was administered with low-dose aspirin (3-5 $\mathrm{mg} / \mathrm{kg}$ ). Anticoagulation was not given in this patient due to massive left cerebral infarction. The risk of hemorrhagic transformation was extremely high in this patient. Upon admission, patient had improved muscle strength. He could not walk but able to raise his arms and legs.

\section{DISCUSSION}

The patophysiology of ischaemic stroke includes thrombosis and embolism. ${ }^{10}$ The risk factors for pediatric stroke are manifold and differ from those in adult stroke. The majority of Arterial Ischemic Stroke (AIS) in children have underlying diseases such as sicke-cell and congenital or acquired cardiac diseases. Among congenital diseases, the cyanogenic ones with right-to-left shunts have the highest complication rates, including hypoxemia, polycytemia or cyanosis, and may evolve with cerebral ischemia in up to $4 \%$ of cases. ${ }^{3,5}$

The patophysiology of ischaemic stroke includes thrombosis and embolism.10 The risk factors for pediatric stroke are manifold and differ from those in adult stroke. The 
majority of Arterial Ischemic Stroke (AIS) in children have underlying diseases such as sicke-cell and congenital or acquired cardiac diseases. Among congenital diseases, the cyanogenic ones with right-to-left shunts have the highest complication rates, including hypoxemia, polycytemia or cyanosis, and may evolve with cerebral ischemia in up to $4 \%$ of cases.3,5

Cardioembolic stroke is a severe condition that may causing difficulties in diagnostic and therapeutic approaches. The clinical diagnosis is based on the findings of a cardiac-transcardiac embolic origin without evidence of other causes of stroke. Cardiac emboli may cause massive, superficial, single large striatocapsular or multiple infarcts in the middle cerebral artery. The features suggestive of cardioembolic stroke are clinically decreased consciousness at onset, rapid regression of symptoms, sudden onset to maximal deficit $<5 \mathrm{~min}$, and visual field defects, neglect, or aphasia. 11,12.

Tetralogy of Fallot is the most common congenital heart disease. TF remains the most common type of congenital heart lesion seen beyond infancy and childhood with about $5 \%$ of patients surviving to the age of 40 years. ${ }^{9}$ Tetralogy of Fallot is one of the conotruncal family of heart lesions in which the primary defect is an anterior deviation of the infundibular septum (the muscular septum that separates the aortic and pulmonary outflows). The consequences of this deviation are (1) obstruction to right ventricular outflow (pulmonary stenosis), (2) ventricular septal defect (VSD), (3) dextroposition of the aorta with override of the ventricular septum, and (4) right ventricular hypertrophy. ${ }^{13,14,15,16}$

Paradoxical embolism is a mechanism of stroke unique to congenital heart disease. The direction and volume of shunted blood in various conditions have a central role in determining the risk of stroke. As paradoxical embolism requires an abnormal communication between the venous and arterial compartments, by definition all patients suspected having had a stroke by this mechanism must have some sort of congenital heart defects. ${ }^{9,17}$

A paradoxical embolism is a type of stroke or arterial thrombosis caused by a thrombus of venous origin through a defect in the heart that creates a potential for right-to-left shunting of blood. A patient with tetralogy of fallot, cyanosis caused by right-to-left shunting. ${ }^{17}$

In the normal circulatory system, the pulmonary capillary bed acts as a filter, preventing embolic material carried by the venous blood from reaching the systemic circulation. A systemic embolic event, including stroke, which is a result of embolic material originating in the venous compartment bypassing the pulmonary capillary filter, is defined as paradoxical embolism. ${ }^{13}$

Cyanosis is the clinical presentation of low oxygen content in systemic arterial blood, resulting from a large volume of venous blood (usually 1-2 L/min) that is shunted directly into the systemic circulation, with the potential of carrying a clot or other embolic material to cause stroke or brain abscess. Fallot's tetralogy and the Eisenmenger syndrome are two of the better known examples of cyanotic conditions. This mechanism of stroke via paradoxical embolism is well established. In cases of infected clot, brain abscess ensues. Such patients are also at risk of iatrogenic events, caused by the inadvertent introduction of small amounts of air into an intravenous line, and special precautions are needed to prevent this complication. ${ }^{13,17}$

Transthoracic echocardiography (TTE) has been variably useful in detecting sources of embolism in stroke patients. In patients with 
clinically apparent heart disease, the yield for Cardiac Source of Embolisms (CSEs) of conventional transthoracic echocardiography (TTE) with agitated-saline injection may exceed $25 \%$, but falls below $10 \%$ otherwise. By contrast, the superior image resolution of transesophageal echocardiography (TEE) permits identification of possible CSEs in more than $50 \%$ of patients without clinically overt heart disease or otherwise unexplained cerebro-vascular events. ${ }^{11,12,18}$

Acute management of pediatric stroke generally follows the guidelines for management of ill children. There are no specific guidelines currently in place for the treatment of stroke in children, although central elements include support treatment, monitoring, and anticoagulation as secondary prevention in certain cases. ${ }^{10}$

The use of anticoagulation is controversial. Anticoagulation is a potentially risky therapy that imposes a variety of lifestyle constraints on patients. As a result, patient education and involvement in the anticoagulation decision is important. The safe use of anticoagulants depends on patient cooperation and a monitoring system that can achieve INR targets on a regular basis. ${ }^{18}$

As paradoxical embolism requires both a clot and an abnormal anatomic communication, treatment should address one of the two: either preventing the formation of more clots by using medication (antiplatelet agents, anticoagulants), or closing off the communication by a mechanical barrier at surgery or catheterization. ${ }^{13,19}$

There is a lack of research on the use of anticoagulants in children. Despite this, use of heparin or low molecular weight heparin may be considered in children with cardiac embolism, arterial dissection, coagulation disorders, and recurrent stroke. Anticoagulant treatment may be indicated in a child with progressive deterioration, or during itial evaluation of a new cerebral infarction. Low-dose aspirin $(3-5 \mathrm{mg} / \mathrm{kg})$ is recommended if anticoagulation is not given. $7,13,19$

Prognosis depends on the extent of brain damage and the underlying disease but recurrence rates are high in most cases. ${ }^{3}$ Not knowing the recurrence rate makes it difficult if not impossible to analyze the effect of any treatment method provided for secondary prevention. Tetralogy of Fallot in this patient carries high risk of recurrent stroke. $^{13,20,21}$

\section{Conclusion}

Although there was no definitive thrombus found on echocardiogram, the clinical profile, electrocardiogram, chest radiography, brain CT scan and echocardiography suggest a cardioembolic stroke associated with tetralogy of Fallot. The source of emboli was by mechanism of paradoxical embolism which is common in cyanogenic conditions, i.e Tetralogy of Fallot. This report draws attention to an interesting association of Tetralogy of Fallot with Cardioembolic stroke in pediatric stroke. Tetralogy of Fallot is best known as the cause of brain abscess. But in this patient, cardioembolic stroke took place

\section{REFERENCES}

[1] Roach ES, Golomb MR, Adams R, Biller J, Daniels S, deVeber $G$, et al. Management of Stroke in Infants and Children: A Scientific Statement From A Special Writing Group of The American Heart Association Stroke Council and The Council on Cardiovascular Disease in the Young. Stroke. 2008;39:2264-2691

[2] Rafay MF. Ischemic Stroke in ChildrenOverview Including an Asian Perspective. J Pak Med Assoc Vol.58, No.7, July 2008.

[3] Filho EM, de Carvalho WB. Stroke in Children. J Pediatr (Rio J). 2009; 85(6):469-479

[4] Ranzan J, Rotta NT. Ischemic Stroke in Children; A Study of The Associated Alterations. Arq Neuropsiquiatr 2004;62(3-A):618-625

[5] Ballerini L, Gimigliano F, Ammirati A, Cifarelli A. Ischemic Stroke in Children-Role of Patent 
Heme, Vol I No 1

January 2019

Foramen Ovale. European Pediatrics Review 2007.

[6] Gottl UN, Gunther G, Kurnik K, Strater R, Kirkham F Arterial Ischemic Stroke in Neonates, Infants, and Children: An Overview of Underlying Conditions, Imaging Methods, and Treatment Modalitis. Seminars in Thrombosis and Hemostasis, volume 29, number 4, 2003.

[7] Kirkham F, Sebire G, Steinlin M, Strater R. Arterial Ischemic Stroke in Children. Review of the Literature and Strategies for Future Stroke Studies. Thromb Haemost 2004;92:697-706

[8] Mackay MT. Stroke in Children. Australian Family Physician 2011;36:11

[9] Krishna CS, Reddy GK, Debta M, Panigrahi NK. Tetralogy of Fallot with Rheumatic Mitral Stenosis: A case report.

[10]Cheng WW, Ko CH, Chan AKH. Pediatric stroke: case series. HKMJ 2002;8:216-20

[11] Lin MS, Chang NC, Lee TS. New Advances in the Diagnosis and Management of Cardioembolic Stroke. Acta Cardiol Sin 2005;21:1_12

[12] Greer DM, Homma S, Furie KL. Cardiac Diseases. In: Mohr JP et al.,eds. Stroke Pathophysiology, Diagnosis, and Management. 5th edition. 2011. Philadelphia : Elsevier Saunders. Pg 814-817.

[13] Hirsch R, Streifler JY. Stroke in Congenital Heart Disease and Patent Foramen Ovale. IMAJ 2005;8:798-802

[14] Barnes C, Newall F, Furmedge J, Mackay M, Monagle P. Arterial Ischemic Stroke in Children. J. Pediatr.Child Health (2004) 40, 384-387

[15] Karl TR. Tetralogy of Fallot: A Surgical Perspective. Korean J Thorac Cardiovasc Surg 2012;45:213-224

[16] Silversides CK, Kiess MK, Beauchesne L, Bradley T, Connelly M, Niwa K, et al. Canadian Cardiovascular Society 2009 Consensus Conference on The Management of Adults with Congenital Heart Disease: Outflow tract Obstruction, coarctation of the aorta, tetralogy of Fallot, Ebstein anomaly and Marfan's Syndrome. Can J Cardiol 2010;26:3: 896-902

[17] Jin KN, Chun EJ, Choi SI, , Ko SM, Han MK, Bae HJ, Park JH. Cardioembolic Origin in Patients with Embolic Stroke: Spectrum of Imaging Findings on Cardiac MDCT

[18] Camm AJ. Stroke Prevention in Atrial Fibrillation-The Unmet Need and Mortality Burden.European Cardiology, 2011;7(3):187-195

[19] Albers GW, et al. Antithrombotic Therapy in Atrial Fibrillation. Chest. 2001;119:194S-206S.

[20] Golomb MR. Strokes in Neonates and Children: Overview. In: Biller J, 2nd ed. Stroke in Children and Young Adults. 2009. Philadelphia: Saunders Elsevier
[21] Uduma UF, Mbiydzela, Ernest Ngu, Mathieu M, Wali M. Childhood Ischemic Stroke: a Report of Two Cases. Global Journal of Health Sciences 2011;3:2:200-205

Email : heme@unbrah.ac.id 
Heme, Vol I No 1

January 2019 